Kamila Orzechowska-Przybyla

HOL - POL/Sonneveld

e-mail: kamilacmgroup@gmail.com

\author{
Alina Niewelt \\ Credin Polska Sp. z o.o. \\ e-mail: alina.niewelt@gmail.com
}

\title{
Tomasz Lesiów
}

Wroclaw University of Economics and Business

e-mail: tomasz.lesiow@ue.wroc.pl

ORCID: 0000-0002-1284-5874

\section{HEALTH RISK ANALYSIS}

AND RISK MANAGEMENT

IN THE LOGISTIC-PRODUCTION CHAIN

AS FACTORS INFLUENCING

THE QUALITY AND SAFETY OF FOOD

ON THE EXAMPLE OF TWO FOOD COMPANIES

\section{ANALIZA RYZYKA ZDROWOTNEGO \\ I ZARZĄDZANIE NIM W ŁAŃCUCHU \\ LOGISTYCZNO-PRODUKCYJNYM \\ JAKO CZYNNIKI WPLYWAJĄCE \\ NA JAKOŚĆ I BEZPIECZEŃSTWO ŻYWNOŚCI \\ W DWÓCH FIRMACH SPOŻYWCZYCH}

DOI: $10.15611 /$ nit.2019.4.04

JEL Classification:Q19

\begin{abstract}
The aim of this study was to identify risks in the quality and safety of food, and to indicate, basing on a risk analysis, the ways of managing potential risks in two different production profile enterprises of the food industry. It was found that potential hazards to the quality and safety for technological process as well as for the other links of the logistics chain were identified, and prevention procedures were established to minimize or completely eliminate these hazards. Moreover, the benefits of risk management were similar, and mainly felt in the constant increase of food producers' awareness of the necessity of safe food production and increase of concern for the health and life of consumers. This in turn contributes to:
\end{abstract}


- development of staff competence,

- improvement of logistic processes to better protect against external factors, unauthorized persons and side effects,

- investments and implementation of new organisational solutions in warehouses and production areas.

Keywords: quality and food safety, risk analysis, risk management, logistics chain.

Streszczenie: Celem pracy była identyfikacja zagrożeń w zakresie jakości i bezpieczeństwa żywności oraz wskazanie, na podstawie analizy ryzyka, sposobów zarządzania potencjalnymi zagrożeniami w dwóch przedsiębiorstwach przemysłu spożywczego o różnym profilu produkcji. Stwierdzono, że zidentyfikowano potencjalne zagrożenia dla jakości i bezpieczeństwa procesu technologicznego oraz pozostałych ogniw łańcucha logistycznego, a także opracowano procedury zapobiegawcze mające na celu minimalizację lub całkowite wyeliminowanie tych zagrożeń. Ponadto zaobserwowano, że korzyści z zarządzania ryzykiem były podobne odczuwalne głównie w stałym wzroście świadomości producentów żywności dotyczącej konieczności produkcji bezpiecznej żywności oraz zwiększonej trosce o zdrowie i życie konsumentów. To z kolei przyczynia się do:

- rozwoju kompetencji personelu,

- usprawnienia procesów logistycznych w celu lepszej ochrony przed czynnikami zewnętrznymi, osobami nieupoważnionymi i skutkami ubocznymi,

- $\quad$ inwestycji i wdrażania nowych rozwiązań organizacyjnych w magazynach i obszarach produkcyjnych.

Słowa kluczowe: jakość i bezpieczeństwo żywności, analiza ryzyka, zarzadzanie ryzykiem, łańcuch logistyczny.

\section{Introduction}

The food industry has been one of the basic branches of the economy for centuries, meaning that a diversity of products is available for purchase and further modification, and that new solutions to meet consumer expectations are introduced. This field is extremely vulnerable to physical, chemical, microbiological and biological hazards due to the numerous links: the companies form a logistics chain, producing the raw materials, semi-finished products and finished products. In literature we can find many studies on types of risks present in each of the branches of the food industry (Kmiećkowiak \& Lesiów, 2009b; Waligora \& Lesiów, 2009). Their main division and the definitions were determined in accordance with the laid down rules of food safety standards and the international standards based on them which increase food security, its health and therefore quality (Joachimiak, 2012; Kmiećkowiak \& Lesiów 2009a).

According to Browerson (1990), a logistics channel (chain) is a group or a certain number of units (companies and institutions), which work together in an integrated way to deliver the right product at the right place and at the right time while maintaining the appropriate quality (product and services) at the lowest possible 
cost. Christopher (2014) defines supply chain as "a network of connected and independent organizations mutually and cooperatively working together to control, manage and improve the flow of materials and information from suppliers to end users". Enarsson (2009) discusses different definitions of logistics and supply chain management.

In a continuous effort to improve the company's efficiency by increasing the scale of operations, the supply chains become longer and more complex through entering a new market and expanding its supplier base, which in turn results in an increase in disturbance or hazard risk. Ensuring security in the supply chain becomes a priority for companies (Kołożyn-Krajewska, 2013). The supply chain includes all phases and functions associated directly or indirectly with satisfying customer needs. It is an integrated management of goods and information flow, a physical network or a network of interrelated organizations, links of the supply chain, which include all kinds of activities, logistics operations that enable the flow of products, services, information from the original supplier to the ultimate customer (Kulińska, 2007).

The risk management process of the supply chain can be characterized as identification and control of risks in the links forming the supply chain and in the internal processes related to transport of goods/services and information, through integrated activities of enterprises that make up the supply chain. The main processes carried out within the supply chain include customer relationship management, customer service management, demand management, order fulfilment, production flow management, supply, development of products and their commercialization (Lupicka-Szudrowicz, 2004).

Each of these processes involves a specific type of risk. When identifying hazards, it is important to consider the risks directly associated with individual companies forming part of the supply chain, as well as risks occurring in mutually realised processes. Interference occurring in one link can cause negative events in subsequent links. The inclusion of risk management into supply chain starts with the preparation of maps of processes taking place in companies of suppliers, processors and customers and then determination of the relationship between these processes. A detailed analysis of the activities carried out within the particular process allows to accurately ascribe it to adequate risk groups (Kulińska, 2007).

Generally accepted principles of food safety that ensure a minimum fulfilment of hygiene, production and logistics requirements are realized over the years within the framework of the HACCP system and its subsequent improvements and developments, as for example the increasingly widespread BRC standard (Dani, 2016; Kołożyn-Krajewska, 2013; Orzechowska-Przybyła, Niewelt, \& Lesiów, 2014; The British Retail Consortium, 2018). On the basis of food safety principles, we can discern three basic food hazards: physical, microbiological and chemical.

The problem of determining full risk in a chain of logistics-production is the subject of very few publications because of frequent separation of logistics processes from production processes (Dudziak, Piekarski, Słowik, Stoma, \& Maj, 2014; 
Miśniakiewicz, 2011; Pia, 2010). This separation is valid for the presentation of specialization within the given logistic or production process. However, looking globally for a practical depiction of activities carried out in the food industry, a comprehensive approach is necessary due to the interdependence of logistics and production processes in the production of safe food. The logistical process affects further production processes and vice versa. The lack of risk determination and potential risks evaluation in logistics and production processes will be reflected on the subsequent stages of logistic and production processes, which may result in the preparation of unsatisfactory product, damaged or threatening the health and life of consumers.

The aim of this study was to identify the most common hazards in quality and food safety at two renowned food industry companies. An additional goal was to indicate the ways to manage the potential risks in these two companies of varying profile.

\section{Materials and methods}

The study involved stages of delivery of raw materials to the selected plants, their internal circulation and processing, storage and transport to the customer. The research was conducted in two plants in 2010-2014. The first factory is specialized in the production of frozen fruit and vegetables, the second - mixes for bakery and confectionery. The study used qualitative research method, applying case studies and the results of audits and complaints cards. The following documents were also used: integrated quality management book, including maps and descriptions of processes, list of risks in the company, risk analysis of raw materials and finished products, equalization, corrective and preventive action.

\section{Health risk analysis and risk management in the logistics chain on the example of the operation of the plant producing frozen fruit and vegetables}

The operations within the framework of the logistic-production processes at the plant producing frozen fruit and vegetables were shown in Fig. 1.

A detailed description of the risks in the logistic-production processes and potential ways of minimizing these risks is shown below.

I. Harvest of the raw material - the stage run at the supplier of agricultural products. Harvest of agricultural products is the last element of agricultural production. This step incurs risk of introduction of physical, chemical and microbiological hazards to the raw material.

1. Physical hazard contamination of the raw material by foreign material, depending on the type of harvesting: mechanical harvesting performed with the use 

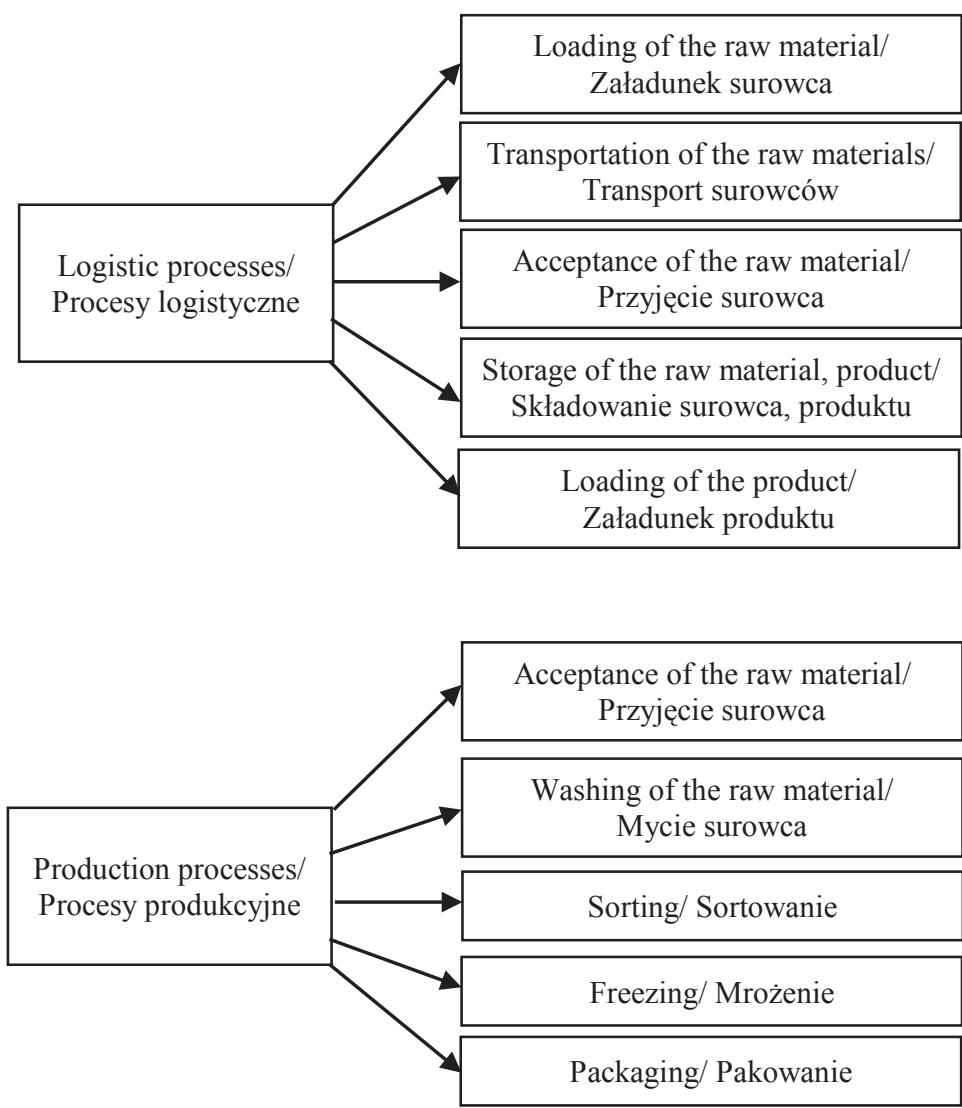

Fig. 1. The operations carried out in the framework of logistics-production processes at the plant producing frozen fruit and vegetables

Rys. 1. Operacje wykonywane w ramach procesów logistyczno-produkcyjnych w zakładzie produkującym mrożone owoce i warzywa

Source: own study.

Źródło: opracowanie własne.

of machinery and equipment carries the possibility of introducing foreign bodies in the form of mechanical parts of the equipment, machines that support the collection, increasing the share of organic and inorganic contaminants by complete removal of plants or their parts as it relates to collection, e.g.: leaves, branches, foreign bodies of animal origin, stones, etc. a/ Mechanical harvest for the production of frozen fruit and vegetables brings a high level of contamination of the raw material which at the same time affects its quality and safety. Minimisation of risk requires conducting systematic inspections of equipment and machinery used to harvest, allowing admission before each use. 
a) manual harvesting carried out selectively by workers employed to harvest. This type of harvesting reduces the risk associated with the introduction of plant, animal, and inorganic contaminations. Supplied raw material is also pre-sorted by maturity and health of fruit and vegetables. The main hazard in the manual collection is the human element - workers employed at harvest. The lack of proper training of workers on matters such as hygiene, risk awareness, refraining from introducing foreign elements into the plantation, and general conforming to the rules of the plantation, may lead to contamination of the raw material with foreign objects such as remnants of food consumed during harvest, plastic parts from damaged packaging used for harvest or other packaging used by employees; contamination may also result from improper harvest, e.g. with the stems or twigs attached, etc. Minimisation of these risks requires appropriate training of the staff employed at harvest on hygiene fundamentals applicable on plantations, required behaviour during the harvest, refraining from bringing unnecessary items to the plantation, and proper harvesting of fruit and vegetables in accordance with specifications of the recipient.

2. Chemical hazards resulting from the improper use of plant protection products and acceleration of ripening. Failure to observe proper pre-harvest periods between application of the chemical agents used in the crops and harvest of fruit and vegetables may lead to exceeding the permissible limits of pesticides and threaten the health and human life. The minimisation of requires the proper use of plant protection products in accordance with the schedule of spraying, observing pre-harvest periods, using only the means permitted by regulations, keeping of appropriate records from performed treatments, participation in training on plant protection products, performing treatments only by authorised personnel.

3. Microbiological hazards may occur through the infection of plantations with micro-organisms, due to the lack of proper plant protection, or unfavourable weather conditions during cultivation and harvest. The most common hazards are moulds and fungi on fruit and vegetables caused by frequent rainfall during the harvest, excessive irrigation and late application of anti-fungal means. Some fruit and vegetables may also develop bacterial or enzymatic diseases. The minimisation of risks requires the proper application of measures against fungi and moulds, observing pre-harvest periods, proper draining of the excess rainwater, groundwater, etc. Raw material transport is carried out with the participation of own transport, the producer's, or external transport of a subcontractor. Risks that may occur at this stage are also physical, chemical and microbiological. The minimisation of risks requires the proper application of measures against fungi and moulds, observing pre-harvest periods, proper draining of the excess rainwater, groundwater, etc.

4. Physical hazards may be associated with improperly conducted loading, packaging damage, improperly prepared vehicles (such as a tractor with semi-trailer) to transport fresh fruit and vegetables, etc. 
5. Chemical hazards can be caused by, e.g., exposure to excessive amount of exhaust gas during transport through the lack of proper protection of the raw materials, overlong transportation time of the raw materials, etc.

6. Microbiological hazards can result from preparing the raw material for transport improperly, for example storing it in closed spaces after harvest, exposure to sunlight, moisture, etc. improper means of transportation for fresh fruit and vegetables, and incorrect transportation, similarly to improper storage. The minimisation of risks involves storage of the harvested raw material in sheltered, ventilated places, and short storage and transportation time.

II. Acceptance of the raw material. This is the primary stage, which allows for better elimination of listed risks coming from the plantation and transportation of the raw materials to the plant. It is extremely important for the wholesomeness of the finished product and its safety during the production process. A proper analysis of the raw material during the delivery to the plant allows to eliminate such hazards as:

a) an excessive amount of foreign matter have been delivered rejecting the raw material incompatible with the required standards, diseases caused by microorganisms, rejecting the raw material with visible signs of disease, unsatisfactory plant protection treatment, suspension of raw materials admittance until field cards from the agricultural producer, indicating proper handling of the plant protection treatments, etc.

III. Production. This stage consists of several technological steps, which aim to remove as many of the physical, chemical or microbiological hazards from the delivered raw material as possible. However, technological steps carried out in the plant may also cause contamination of the raw materials or intermediate products by improper procedures, misbehaviour of production workers and executives during production, or incorrect qualitative, microbiological, or chemical analysis, etc.

Examples of contamination of the raw materials/intermediate products:

a) physical hazards caused by parts of the equipment and machines through their improper operation or use during production, damage, etc. The minimisation of risks requires conducting systematic maintenance of the equipment, and daily controls qualifying for production;

b) chemical contamination caused by the improper use of cleaning agents in the production area, improper storage of chemicals and raw materials, or wrong application of cleaning agents for washing fruit and vegetables. The minimisation of risks requires supervision and keeping appropriate records of cleaning agent use, controlling for cleanliness and hygiene, including the use of clean belts, etc.;

c) microbiological hazards resulting mainly from the poor storage of the delivered raw materials and failure to ensure cleanliness and hygiene in the production area. The minimisation of risks requires storage in refrigerated chambers, application of the first in first out (FIFO) principle, temperature control for raw material storage, and keeping relevant records. 
IV. Storage is one of the final steps during which attention should mainly focus on the possibility of physical and microbiological hazards. Storage of products outside designated zones for individual products and raw materials creates cross-contamination risk. This is one of the fundamental errors that occur during the storage phase for the finished product. In addition, there is a risk of physical or microbiological harm as a consequence of packaging damage during storage. In the case of deep-frozen products storage, microbiological risk occurs, which may arise in the absence of proper temperature control or failure of the cold chamber. The minimisation of risks is carried out through the permanent control of the temperature in cold chambers, using replacement units in the event of power outage, and controlling the raw material for the proper storage and state of packaging.

The analysis performed indicates the need of permanent monitoring of the raw materials/intermediates/products circulation and systematic control of records, procedures and behaviour during production and storage, through which it is possible to maintain food safety. Each stage of the production-logistics chain must be subjected to observation, analysis and interpretation and implementation of the appropriate records in the form of procedures in order to eliminate potential and existing threats. In the analysed plant, many errors were committed during the first years of operation, which caused numerous complaints. The implementation of the HACCP system helped to eliminate most risks, and in the following years risk was minimized by $90 \%$ compared to the initial situation through further improvement of the system and implementation of further food safety systems.

An extremely important factor for ensuring quality and food safety is cooperation between agricultural producer and plant processor (Orzechowska-Przybyła, Niewelt, Kosiorowska, \& Lesiów, 2011). Proper specifications of the raw materials passed by the processor to the agricultural producer, allows to eliminate a significant amount of foreign bodies in the raw materials already at the harvest stage. In addition, in recent years, certain limitations have been imposed onto agricultural producers through the legislative system, requiring them to use only certain types of plant protection products and to limit their quantity, which, in turn, has an impact on the health quality of the raw materials entering the market.

Another very important element in a comprehensive approach to logisticsproduction chain is a need to conduct regular internal audits and audits of agricultural producers (Orzechowska-Przybyła et al., 2014). By auditing the agricultural producers and processor records, conducting regular inspections of plants and analysing the complaints they receive, it is possible to estimate the risks in transportation, production and storage, and then to develop mechanisms to minimise them. Conducting such treatments allows to ameliorate the products' wholesomeness and their market value.

Minimising risks in logistics-production chain is shown in Fig. 2. 


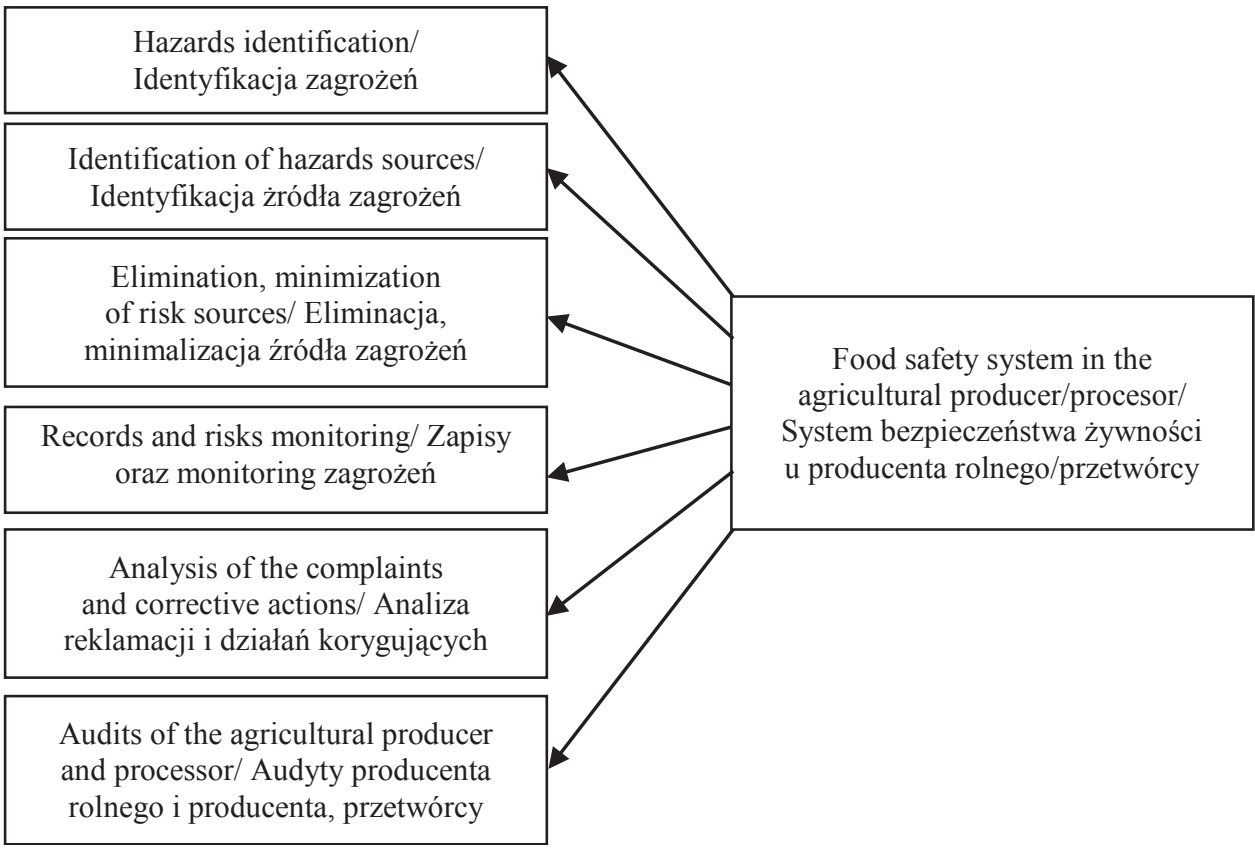

Fig. 2. Minimising risks in logistics-production chain

Rys. 2. Minimalizacja ryzyka w łańcuchu logistyczno-produkcyjnym

Source: own study.

Źródło: opracowanie własne.

Implementation and development of food safety systems significantly contributes to the minimisation of existing hazards in the logistic-production chain. However, the system should undergo regular reviews and changes in accordance with the evolving conditions of the company's internal operation. Properly designed system, its operation and control can guarantee a high food health quality and safety, and provide the market with products expected by a conscious customer.

\section{Health risk analysis and risk management in the logistics chain, using a plant producing mixes for bakery and confectionery as an example}

In the case of the second plant studied, stages of production-logistics in the process of implementing customer order, together with potential risks, are shown in Fig. 3 and in Table 1. As for particular references to the risks related to the food health security in this study, the stages of implementing client orders having the greatest impact on health safety of food will be discussed in detail. 


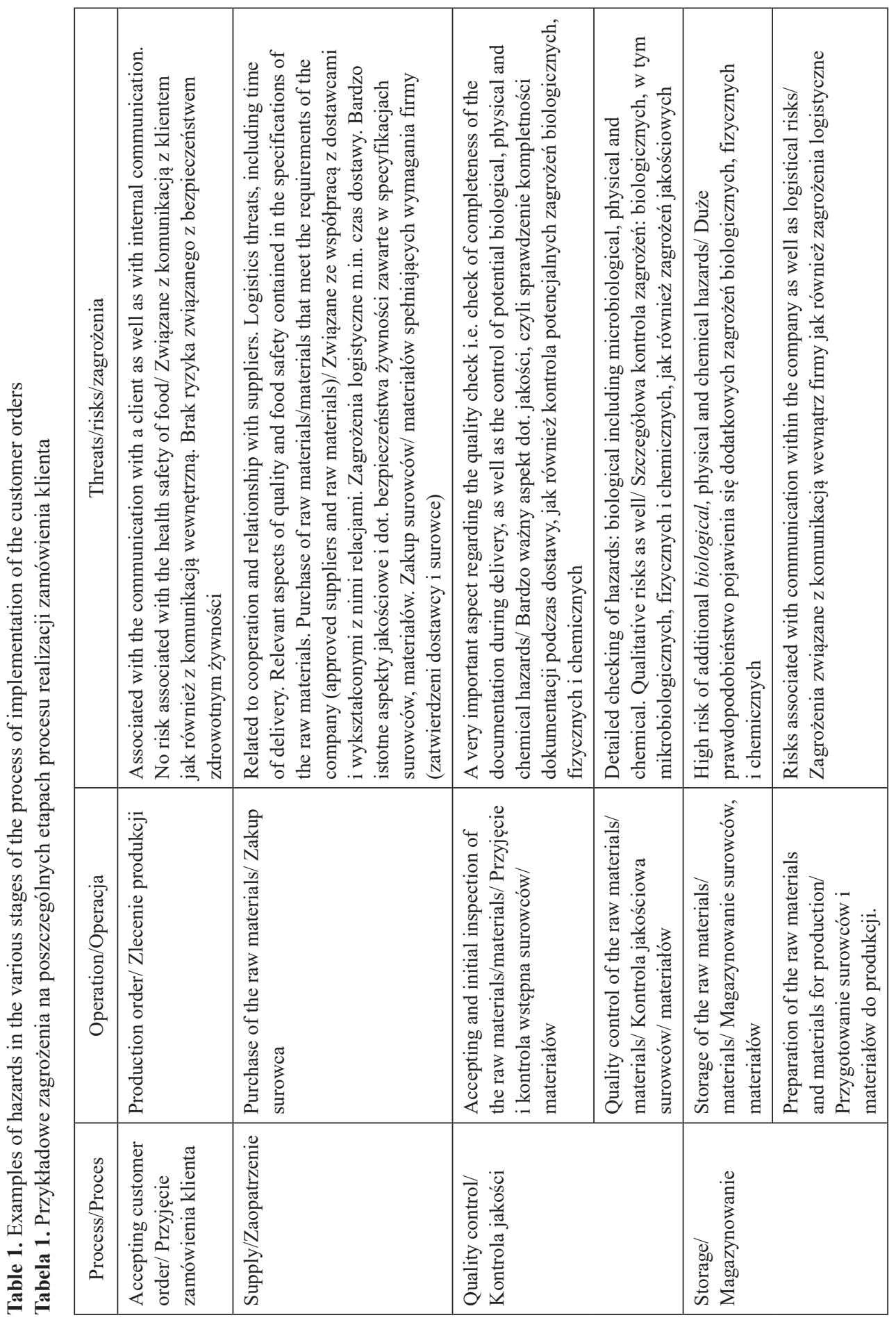




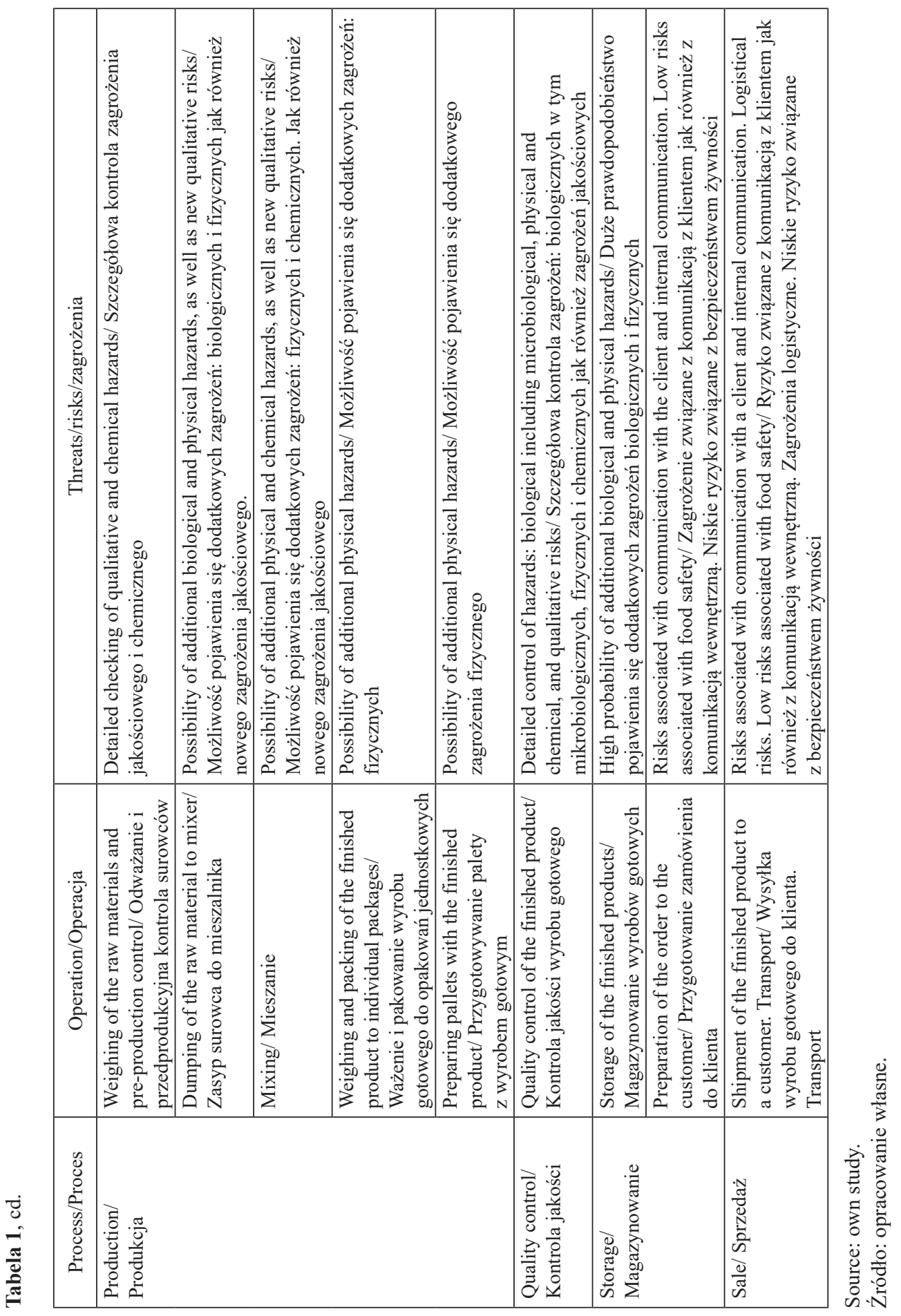




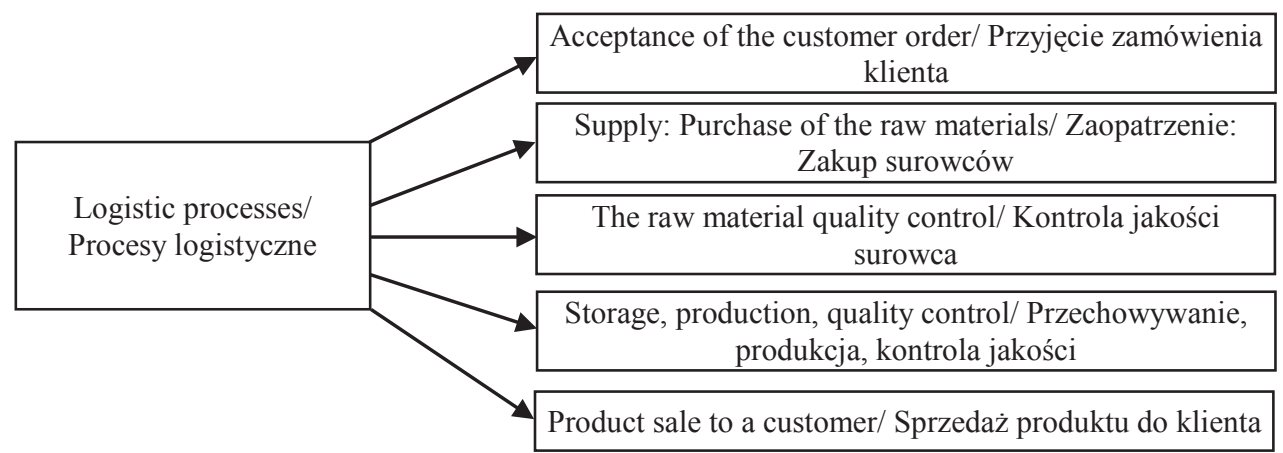

Fig. 3. The operations carried out in the framework of logistics-production processes at the plant producing mixes for bakery and confectionery

Rys. 3. Operacje realizowane w ramach procesów logistyczno-produkcyjnych w zakładzie produkującym mieszanki piekarskie i cukiernicze

Source: own study.

Źródło: opracowanie własne.

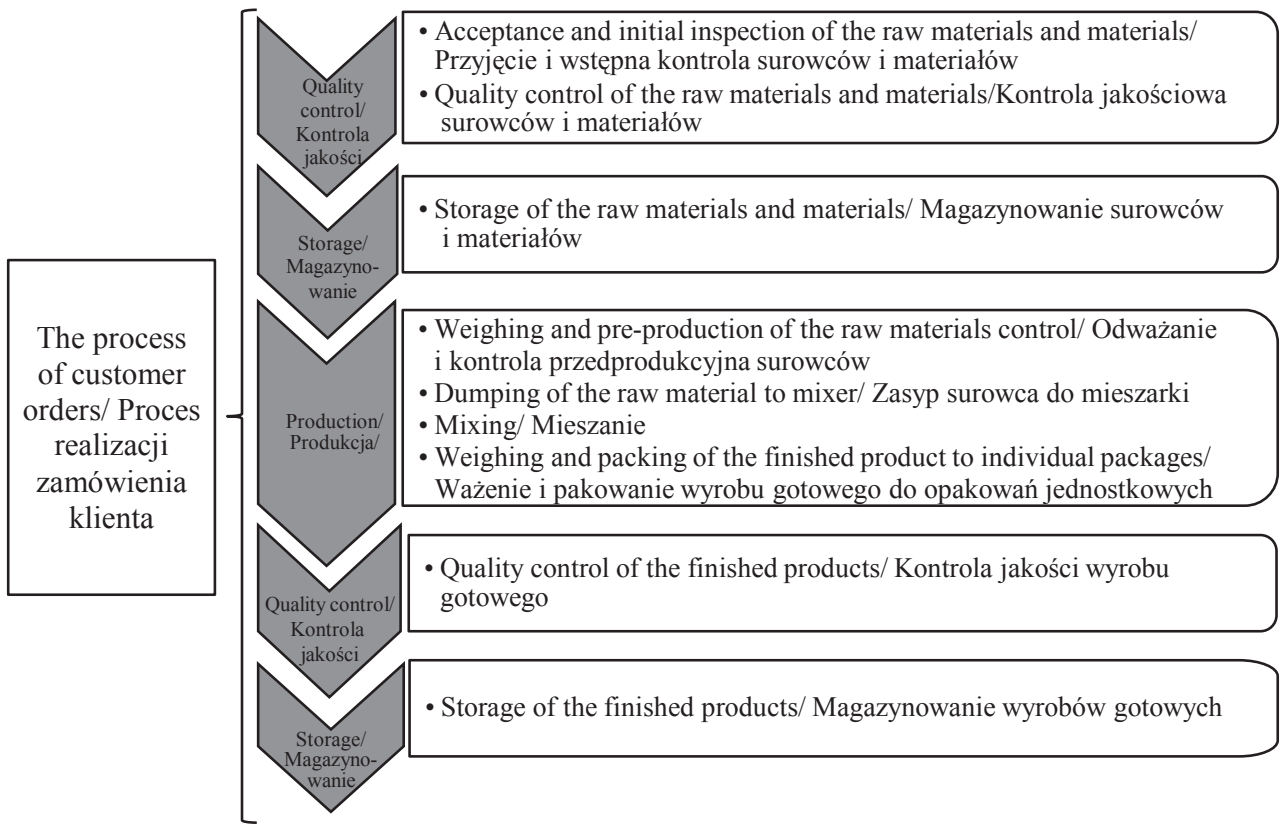

Fig. 4. Stages in the process of implementation of customer orders that have the greatest impact on health to ensure food safety in the supply chain

Rys. 4. Etapy procesu realizacji zamówienia klienta mające największy wpływ na zapewnienie bezpieczeństwa zdrowotnego żywności w łańcuchu dostaw

Source: own study.

Źródło: opracowanie własne. 
In connection of a particular focus on the health of food security risk in this study it will be later discussed in detailed stages of the implementation of the client orders having the greatest impact on health safety of food (Fig. 4). In the context of the particular reference to the risks of food safety for health first the acceptance of customer orders because they have the greatest impact on health safety of food will be discussed (Fig. 4).

I. Quality Control

1. Accepting and initial inspection of the raw materials and materials. At this stage, the most important thing is to control the following risks:

- qualitative

Table 2. Accepting and initial inspection of the raw materials and materials

Table 2. Czynności podczas przyjęcia i kontroli wstępnej surowców i materiałów

\begin{tabular}{|c|c|}
\hline $\begin{array}{l}\text { Operation during admission/ } \\
\text { monitoring risks/ Czynność podczas } \\
\text { przyjęcia/ monitoring zagrożeń }\end{array}$ & The limit of acceptability/ Granica akceptowalności \\
\hline $\begin{array}{l}\text { Checking the transport documents } \\
\text { and certificates for the raw material, } \\
\text { materials, goods for completeness/ } \\
\text { Sprawdzenie kompletności } \\
\text { dokumentów przewozowych i atestów } \\
\text { dla surowca, materiałów, towarów }\end{array}$ & $\begin{array}{l}\text { Certificate of quality and commercial identification } \\
\text { document (HDI) in the case of the raw materials of animal } \\
\text { origin must be attached to each delivery/ Atest jakościowy } \\
\text { i handlowy dokument identyfikacyjny (HDI) w przypadku } \\
\text { surowców pochodzenia zwierzęcego dołączone do każdej } \\
\text { dostawy }\end{array}$ \\
\hline $\begin{array}{l}\text { Checking whether the delivery is } \\
\text { compatible with order: the subject, } \\
\text { the quantitative status of delivery of } \\
\text { the raw material, materials and goods/ } \\
\text { Sprawdzenie czy dostawa jest zgodna z } \\
\text { zamówieniem: przedmiot, stan ilościowy } \\
\text { dostawy surowca, materiału, towaru }\end{array}$ & $\begin{array}{l}\text { The status should agree with transport documents and the } \\
\text { contract/ order/ Stan powinien się zgadzać z dokumentami } \\
\text { przewozowymi i zamówieniem }\end{array}$ \\
\hline $\begin{array}{l}\text { Checking the expiration date of } \\
\text { raw materials, materials, goods/ } \\
\text { Sprawdzenie daty minimalnej trwałości } \\
\text { partii surowca, materiału, towaru }\end{array}$ & $\begin{array}{l}\text { Accepted raw materials, materials, and goods must not } \\
\text { be past their expiration date. The expiration date on the } \\
\text { packaging must be the same as the one on the certificate of } \\
\text { quality/ Przyjmowany surowiec, materiał, towar musi być } \\
\text { w dacie minimalnej trwałości. Data minimalnej trwałości } \\
\text { z opakowania musi być zgodna z datą z certyfikatu jakości }\end{array}$ \\
\hline
\end{tabular}

- biological

\begin{tabular}{|l|l|}
\hline \multicolumn{1}{|c|}{$\begin{array}{c}\text { Operation during admission/ monitoring risks/ } \\
\text { Czynność podczas przyjęcia/ monitoring zagrożeń }\end{array}$} & \multicolumn{1}{c|}{$\begin{array}{c}\text { The limit of acceptability/ Granica } \\
\text { akceptowalności }\end{array}$} \\
\hline $\begin{array}{l}\text { Checking whether there are no visible signs of } \\
\text { pest presence on the packaging, pallets, etc./ }\end{array}$ & $\begin{array}{l}\text { There are no visible traces of pest presence } \\
\text { or residue/ Brak widocznych śladów } \\
\text { Sprawdzenie czy nie ma widocznych śladów } \\
\text { bytności szkodników na opakowaniach, paletach } \\
\text { itp. }\end{array}$ \\
\hline
\end{tabular}


- physical

\begin{tabular}{|l|l|}
\hline \multicolumn{1}{|c|}{$\begin{array}{c}\text { Operation during admission/ monitoring } \\
\text { risks/ Czynność podczas przyjęcia/ } \\
\text { monitoring zagrożeń }\end{array}$} & The limit of acceptability/ Granica akceptowalności \\
\hline $\begin{array}{l}\text { Visually checking the cleanliness of means } \\
\text { of transport (hygienic state of means of } \\
\text { transport)/ Sprawdzenie wizualnie czystości } \\
\text { środka transportowego (stan higieniczny } \\
\text { środka transportowego). }\end{array}$ & $\begin{array}{l}\text { Means of transport must be clean and without } \\
\text { unpleasant smells/ Środek transportowy musi być } \\
\text { czysty, bez nieprzyjemnego zapachu }\end{array}$ \\
\hline $\begin{array}{l}\text { Checking the status of the external individual } \\
\text { and bulk packaging of the raw material, } \\
\text { material and goods/ Sprawdzenie stanu } \\
\text { zewnętrznego opakowań zbiorczych, } \\
\text { jednostkowych surowca, materiałów, towarów }\end{array}$ & $\begin{array}{l}\text { No damage of the individual and bulk packaging } \\
\text { - the inner layer, directly adjacent to the raw } \\
\text { materials, materials, goods/ Brak uszkodzeń } \\
\text { opakowania zbiorczego, jednostkowego - warstwy } \\
\text { wewnętrznej, bezpośrednio przylegającej do } \\
\text { surowca, materiału, towaru }\end{array}$ \\
\hline $\begin{array}{l}\text { Checking the status of the external } \\
\text { individual and bulk packaging of the raw } \\
\text { materials, materials and goods/ Sprawdzenie } \\
\text { stan zewnętrzny opakowań zbiorczych, } \\
\text { jednostkowych surowca, materiałów, towarów }\end{array}$ & $\begin{array}{l}\text { Packaging undamaged, clean, no mould/ } \\
\text { Opakowania nieuszkodzone, czyste również } \\
\text { niezapleśniałe }\end{array}$ \\
\hline $\begin{array}{l}\text { Checking the condition of pallets/ } \\
\text { Sprawdzenie stanu palet }\end{array}$ & $\begin{array}{l}\text { Pallets undamaged, clean, dry, without visible traces } \\
\text { of mould/ Paleta nieuszkodzona, czysta, sucha, bez } \\
\text { widocznych śladów pleśni }\end{array}$ \\
\hline
\end{tabular}

- chemical

\begin{tabular}{|c|c|}
\hline $\begin{array}{c}\text { Operation during admission/ } \\
\text { monitoring risks/ Czynność } \\
\text { podczas przyjęcia/ monitoring } \\
\text { zagrożeń }\end{array}$ & The limit of acceptability/ Granica akceptowalności \\
\hline $\begin{array}{l}\text { Checking if steps have been taken } \\
\text { to minimize cross contamination } \\
\text { risk with food allergens (stage } \\
\text { of supplier)/ Sprawdzenie } \\
\text { czy zostały podjęte kroki do } \\
\text { minimalizacji ryzyka zakażenia } \\
\text { krzyżowego alergenami (etap } \\
\text { dostawcy). }\end{array}$ & $\begin{array}{l}\text { Checking if steps have been taken to minimize cross } \\
\text { contamination risk with food allergens (stage of supplier). } \\
\text { Allergenic and non-allergenic raw materials must be submitted } \\
\text { on separate pallets in undamaged packages. The allergenic } \\
\text { raw materials must be properly marked on the label./ Surowce } \\
\text { alergenne i niealergenne złożone na osobnych paletach w } \\
\text { nieuszkodzony opakowaniach. Surowce alergenne odpowiednio } \\
\text { oznakowanie na etykiecie. }\end{array}$ \\
\hline $\begin{array}{l}\text { Sampling of the raw materials } \\
\text { for quality control takes into } \\
\text { account minimizing the risk of } \\
\text { the allergen cross-contamination/ } \\
\text { Pobór prób surowców do } \\
\text { kontroli jakości uwzględniający } \\
\text { minimalizację ryzyka zakażenia } \\
\text { krzyżowego alergenami }\end{array}$ & $\begin{array}{l}\text { Sampling of raw materials must be made with clean equipment. } \\
\text { Raw materials sampled must not have any contact with any } \\
\text { other raw material. Packages from which the sample is taken } \\
\text { should be properly secure/ Pobieraj próby surowców zawsze } \\
\text { czystym sprzętem poborowym. Nie dopuszczaj do kontaktu } \\
\text { z innym surowcem surowca z którego pobierasz próbę. } \\
\text { Prawidłowo zabezpieczaj opakowania, z których została } \\
\text { pobrana próba. }\end{array}$ \\
\hline
\end{tabular}

Source: own study.

Źródło: opracowanie własne. 
2. Quality control of the raw materials and materials. Hazards that need to be specially controlled for at this stage are:

- microbiological, i.e., mesophilic aerobic microorganisms, coliform bacteria, Salmonella, yeast and moulds, Staphylococcus aureus, Bacillus cereus, Bacillus subtilis, Listeria monocytogenes. Controlled by analysing the results of microbiological tests received from suppliers or commissioned by the company.

- biological, i.e., storage pests and their residues. Controlled by a visual check of the reference samples of the raw materials, audits at suppliers.

- physical, i.e., foreign bodies such as wood splinters, glass, plastic, paper, metal, etc. Controlled by checking reference sample of the raw materials using sieve analysis, audits at suppliers.

- chemical, i.e. heavy metals, pesticides and their residues. Controlled by analysis of the physico-chemical results received from suppliers or commissioned by the company.

If any of the parameters do not meet the requirements set by the company and accepted by the supplier, the raw material is not approved for production and launch of the complaint process. At this stage quality characteristics and appropriate parameters such as colour, flavour profile, granulation, $\mathrm{pH}$, smell etc. are monitored as well. The raw material is put into production if it fulfils the criteria, or returned to the supplier if it does not. Conditional production formula allowing for conditional use of the raw material in the production may also be devised.

II. Storage of the raw materials and materials.

1. Hazards that need to be specially controlled for at this stage are:

- biological i.e., storage pests and their residues. Controlled by respecting GHP principles in securing buildings against pests, regular hygienic audits of the storage area. If the raw material is contaminated by the storage pests it is not approved for production and is disposed of.

- physical i.e., foreign bodies. Controlled by reducing the damage of packaging during storage, as well as daily monitoring of the raw materials storage conditions (temperature and air humidity). If the packing of the raw material is damaged the raw material should be disposed of. If the recommended temperature and air humidity are exceeded during storage, the quality control department which evaluates whether the raw materials can be released for production or to be disposed of should be informed about it.

- chemical i.e., allergens. Controlled by the use of allergen management system, which aims to minimize the risk of cross-contamination by the storage of the allergenic raw materials only in designated places and not admission to the packaging damage. If it is suspected that as a result of negligence crosscontamination could happen, risk analysis should be performed and on the basis of it the decision should be made whether the raw material can be used for production or should be disposed of. 


\section{Production}

1. Storage of the raw materials and materials. Hazards that need to be specially controlled for at this stage are:

- qualitative, i.e., weighing of the raw materials according to the production recipe, in particular in the case of the limited food additives e.g. preservatives. Controlled by filling the system documents and control of weighed amounts of the raw materials every time before the shift and after its completion. In the case of mistakenly weighted the raw material identified before its use in the production, it must be found and weighed correctly. If the raw material has already been used in the production this fact should be reported to the quality control department, which will check the production batch and will refer the matter to the research and development department, which will develop a recipe throughput, so called rework.

- chemical i.e., allergens. Controlled by the use of good manufacturing practices minimizing the risk of cross-contamination of the raw materials, by weighing allergenic and no allergenic materials in separate rooms, weighing allergenic materials with division for individual allergens including weighing order, as well as strict compliance with the hygiene rules prevailing during weighing of the raw materials. Dumping of the raw materials to mixer. The hazard that needs to be specially controlled for at this stage is indicated order. Should any raw material incompatible with the production recipe be dumped into the mixer, quality control department must be notified and check the production batch to decide on its system release or blocking. If the batch is systemically blocked the research and development department will develop a throughput recipe, called "rework".

- biological i.e., storage pests and their residues, and physical i.e. foreign bodies. Controlled by checking each package of the raw material dispensed into the mixer. If the operator notices any abnormalities in the appearance of the raw material, such as clusters, remains of pests or foreign particles, the unacceptable raw material is deposited in a place designed for non-compliant materials and is not dispensed into the mixer. The operator requests a new packet from the storage, and only uses it after checking that the new portion of the raw material is not questionable.

2. Dumping of raw material to the mixer - at this stage the risks are controlled in a special way:

- qualitative, i.e., dumping of raw material to the mixer strictly according to the production recipe, in terms of quality, quantity and according to the indicated order. If dumping of raw material happens incompatible with the production recipe quality control department must be notified. It will check the production batch and shall decide on its system release for sale or lock for reasons of quality. If the batch is systemically blocked the research and development department will develop a recipe throughput rework, in short so called rework. 
- biological i.e., storage pests and their residues and physical i.e. foreign bodies by controlling each package of raw material dispensed/dozed into the mixer. If the operator notices any abnormalities in the appearance of raw material such as clumping, the remains of pests or foreign particles, inconsistent raw material is deposited in a place designed for non-compliant materials and not dumped into the mixer. The operator gets the new packaging from the store and after noting that it does not raise any doubt just dumps it to the mixer.

3. Mixing. Hazards that need to be specially controlled for at this stage are:

- qualitative, i.e., the time of mixing. The mixing time is controlled automatically and after its completion, the operator must proceed with the unloading of the finished product from the mixer. If for some reason mixing was too short (power outage), the mixer must be turned back on and mixing continued until the end of the appointed time; if it lasted too long (operator error) it is necessary to pack the finished product into individual packages and to inform the department of quality control, which will decide whether the finished product may be allowed for sale, or to be developed according with throughput recipe.

- physical, extraneous and chemical i.e. lubricants derived from the production line. In order to eliminate such risks, GHP and GMP rules must be obeyed, and systematic hygiene controls of production area, maintenance and inspection of the machinery according to schedule maintenance, as well as monitoring of the sifter, magnet and metal detector must be conducted. If there are any irregularities in the work of the sifter, magnet or metal detector, the supervisor must be informed about this fact as quickly as possible, so they can arrest the batches of finished products produced since the last inspection of indicated devices. Then, the department of maintenance and quality control is informed.

4. Weighing and packaging of the finished products to individual packages. Hazards that need to be specially controlled for at this stage are physical, i.e. foreign bodies, by respecting principles of GHP and GMP in production. This is the last stage in which the operator is in contact with the unpacked, finished product. Therefore, it is very important to prevent the contamination of the finished product.

IV. Quality control

1. Quality control of the finished product. Hazards that need to be specially controlled for at this stage are:

- microbiological i.e., mesophilic aerobic microorganisms, coliforms bacteria, Salmonella, yeasts and moulds, Staphylococcus aureus, Bacillus cereus, Bacillus subtilis, Listeria monocytogenes. Controlled by analysing the results of microbiological tests.

- biological i.e., storage pests and their residues. Controlled by visual inspection reference sample of the finished products.

- physical i.e., foreign bodies e.g. splinters, glass, plastics, paper, metal, etc. Controlled by checking a reference sample of the finished products. 
- chemical i.e., heavy metals, pesticides and their residues and allergens. Controlled by analysis of the physico-chemical test results and the presence/levels of allergens.

If the finished product has the appropriate parameters such as colour, flavour profile, granulation, $\mathrm{pH}$, smell, etc., it is approved for sale. If any of the parameters does not meet the requirements established by the company, the finished product is not approved for sale and follows an investigation process as to the causes of noncompliance, a so-called analysis of the sources of the problem (root causes analysis, RCA). As a result of this investigation process, decisions are taken on the corrective actions and preventive measures.

\section{Storage}

1. Storage of the finished products. Hazards that need to be specially controlled for at this stage are:

- biological i.e.. storage pests and their residues. Controlled by respecting GHP principles in securing buildings against pests, regular hygienic audits of the storage area. If the finished product is contaminated by storage pests, it is not authorized for sale and will be disposed of.

- physical i.e., foreign bodies. Controlled by reducing the damage to the packaging during storage, as well as by daily monitoring of the finished products' storage conditions (temperature and air humidity). If the packaging is damaged, the finished product should be disposed of. If the recommended temperature and humidity during storage is exceeded, the department of quality control should be informed about this fact, and should decide whether the finished products may be allowed for sale or should be disposed of.

From the point of view of the food producer, everything should be done according to risk analysis to produce food that is safe and healthy for the consumer. Therefore, since there are all kinds of hazards on the various stages of production-logistics chain, available preventive measures allowing for their minimisation must be taken. It is also vital to note the very important influence of the human factor in ensuring food safety throughout the supply chain: personnel should possess the adequate knowledge and skills so that high awareness and self-control takes precedence over routine, habit and laziness.

Hazard, which is common to all stages of the implementation of customer order and may appear in each link of the supply chain, is referred to as so-called protection system against intentional food contamination or Food Defence. Food Defence is any action that the company must take in order to prevent intentional contamination of food products by biological, chemical, physical or radiological factors, which cannot be expected through regular risk analysis and which may arise in connection with the activities of people as the source of contamination (Bogadi, Banović, \& Babić, 2016; Food defense, n.d.). Food Defense is the protection of food products from intentional contamination or adulteration by biological, chemical, physical, or radiological agents. It addresses additional concerns including physical, personnel 
and operational security. Europe has started revising its rules concerning the safety of products throughout the supply chain. The main hazard is malicious contamination of food with toxic materials, sabotage in the supply chain and the use of food for terrorist or criminal activities. The attacks in this form may lower the reputation of brands of global companies and more drastic situations can lead to disease or death of consumers (QAP, n.d.). A system of protection against intentional food contamination affects all entities and processes in the supply chain (Fig. 5).

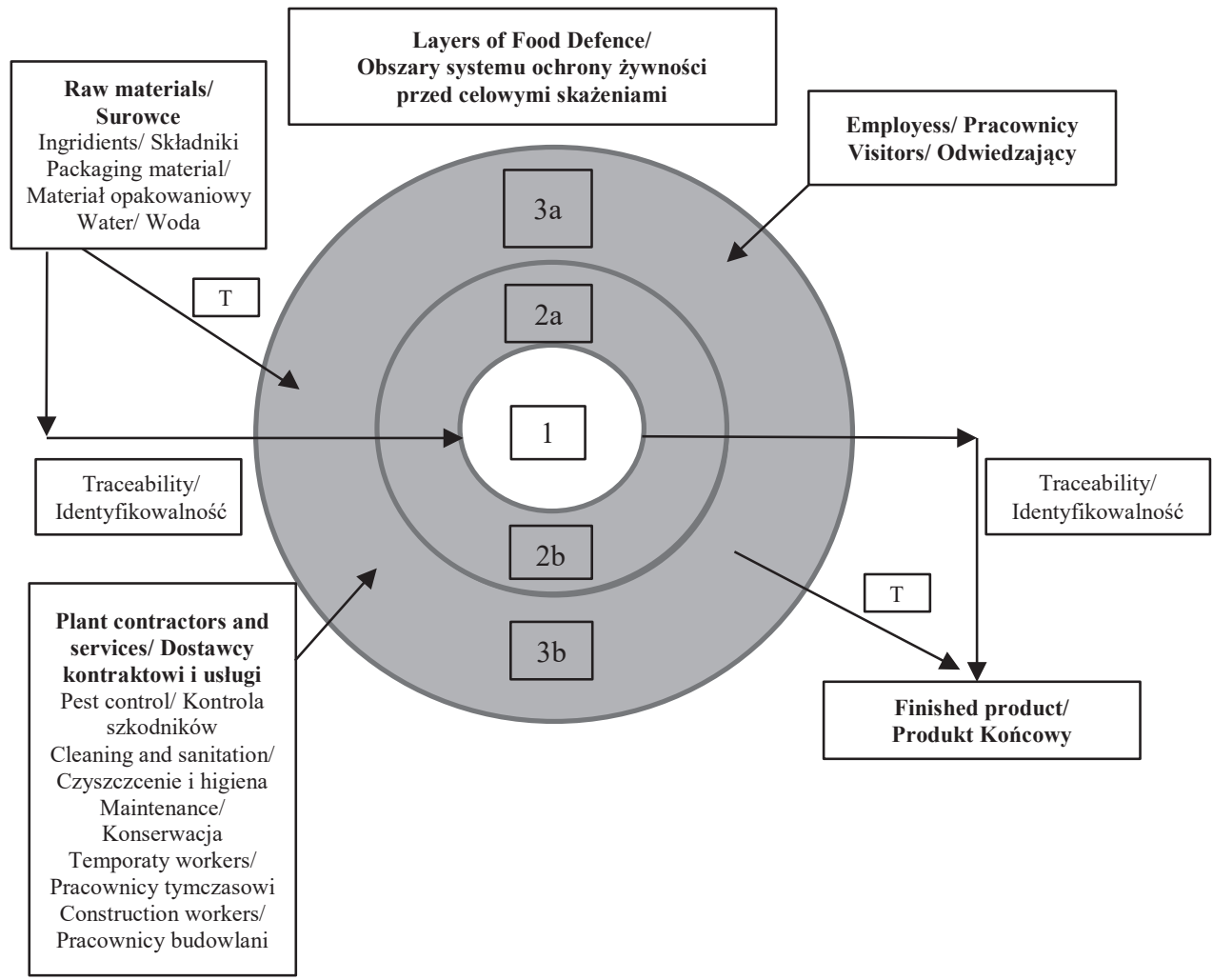

Legend/ Legenda

1 - Process/ Proces; 2a - Plant/ Zakład; $2 b$ - Authorized control of entry/ Kontrola autoryzowana wejścia; $3 a$-Perimeter/Perymeter (otoczenie), 3b-Prevention from unauthorized entry/Zabezpieczenie przed nieautoryzowanym wejściem

$\mathrm{T}$ - Transportation/ Transport

Fig. 5. The system of protection against intentional food contamination Rys. 5. System ochrony przed umyślnym zanieczyszczeniem żywności

Source: (IFT, n.d.).

Źródło: (IFT, n.d.). 


\section{Conclusions}

Similarities in the risk analysis presented in both plants are significant, and include among others:

- the microbiological hazards that may occur at each stage of production-logistics chain, and the basic ways to minimise them. These are identical in each plant of food industry and require the highest hygiene of production workers, maintenance of cleanliness in production and storage, compliance with technological regime. The ways to identify these risks are the laboratory analyses carried out by on-site microbiological laboratories or external laboratories.

- chemical hazards that may be present in the raw materials, semi-finished products or in food production as a result of errors and omissions. The methods of identification of those are meticulous quality controls, taking into account the physico-chemical measurements, e.g. content of heavy metals, pesticides, etc., and the best manufacturing practice ensuring the proper execution of production processes in terms of technology (allergens, cleaning (CIP) (Mierzejewska, Diakun, Piepiórka-Step, \& Zając, 2013), the chemicals coming from machines).

- physical hazards that may occur at any stage of production-logistics chain, because their source may be raw materials, semi-finished products, transport, storage, production process, distribution and even the customer or the consumer. Physical hazards are the most likely and, at the same time, the most controversial because they may arise at any stage, with each entity of the chain creating added value. The way to minimise physical hazards is very similar in almost every plant producing food and includes, among others, security of products during shipping and storage, the use of devices such as sieves, metal clamps, magnets, electromagnets, metal detectors or X-ray detectors to reduce physical hazards in the production process, and quality control of finished products, such as sieve analysis.

The above-mentioned risks are typical for the food industry and are present in all food processing and production plants. However, the way to identify and minimize them is different in every case, and in a large extent depends on technology used and on the type of production.

\section{References}

Bogadi, N. P., Banović, M., \& Babić, I. (2016). Food defence system in food industry: Perspective of the EU countries. Journal of Consumer Protection and Food Safety. Retrieved from https://www. bing.com $/$ search? $\mathrm{q}=\% 2 \mathrm{Fknowledge}+$ center $\% 2 \mathrm{Fcontract}+$ reports $\% 2 \mathrm{Ffood}+$ defence + resource + list $+2016 \& q s=$ n\&form $=\mathrm{QBRE} \& \mathrm{msbsrank}=0 \_0 \_0 \& \mathrm{sp}=-1 \& \mathrm{pq}=\% 2$ Fknowledge + center $\% 2$ Fcontract + reports $\% 2 \mathrm{Ffood}+$ defence + resource + list $\& \mathrm{sc}=0-61 \& \mathrm{sk}=\& \mathrm{cvid}=\mathrm{E} 3 \mathrm{~B} 30 \mathrm{E} 3 \mathrm{~B} 5 \mathrm{~B} 474524 \mathrm{BB}-$ C65364A2CA8EC5.

Browerson, D.J. (1990, July-August). The strategic benefit of logistics alliances, Harvard Business Review, 23-25. 
Christopher, M. (2014). Logistics and supply chain management. creating value - adding networks. Upper Saddle River, N.J.: Prentice Hall. Retrieved from https://books.google.pl/books?id=IQgWVahxO3UC\&printsec $=$ frontcover\&hl $=$ pl\&source $=$ gbs_ge_summary_r\&cad $=0 \# \mathrm{v}=$ onepage $\& \mathrm{q} \& \mathrm{f}=$ false)

Dani, S. (2016). Zarządzanie łańcuchem dostaw żywności. Warszawa: Wydawnictwo Naukowe PWN SA.

Dudziak, A., Piekarski, W., Słowik, T., Stoma, M., \& Maj, G. (2014). Zarządzanie ryzykiem w logistyce dostaw surowców i produktów w transporcie drogowym. Logistyka, 6, 34-39.

Enarsson, L. (2009). What do we really mean by supply chain management? Supply Chain, quarter 1. Retrieved from https://www.supplychainquarterly.com/articles/228-what-do-we-really-mean-bysupply-chain-management

Joachimiak, I. (2012). ISO 22000:2005 and ISO 9001:2008 in the food industry management: Integration or replacement? (review paper). Nauki Inżynierskie i Technologie, 1(4), 9-15.

Kmiećkowiak, A., \& Lesiów, T. (2009a). Systemy zarządzania jakością i ich integracja w przemyśle żywnościowym - praca przeglądowa. Prace Naukowe Uniwersytetu Ekonomicznego we Wrocławiu. Nauki Inżynierskie i Technologie, 1(57), 47-71.

Kmiećkowiak, A., \& Lesiów T. (2009b). Trudności związane z funkcjonowaniem systemu HACCP i sposoby ich przezwyciężania w wybranym zakładzie piekarniczym. Prace Naukowe Uniwersytetu Ekonomicznego we Wroctawiu. Nauki Inżynierskie i Technologie, 1(57), 72-100.

Kołożyn-Krajewska, D. (Ed.). (2013). Higiena produkcji żywności. Warszawa: Wydawnictwo SGGW.

Kulińska, E. (2007). Zarządzanie ryzykiem w łańcuchu dostaw. Logistyka, 1, 18-21.

Łupicka-Szudrowicz, A. (2004). Zintegrowany tańcuch dostaw w teorii i praktyce gospodarczej. Poznań: Wydawnictwo AE w Poznaniu.

Mierzejewska, S., Diakun, J., Piepiórka-Stepuk, J., \& Zając, M. (2013). Mycie w systemie CIP wybranych elementów instalacji przesyłowych. Nauki Inżynierskie i Technologie, 3(10), 70-79.

Miśniakiewicz, M., (2011). Czynniki warunkujące jakość i bezpieczeństwo zdrowotne pieczywa. Zeszyty Naukowe Uniwersytetu Ekonomicznego w Krakowie, 851, 35-52.

Orzechowska-Przybyła, K., Niewelt, A., Kosiorowska, M., \& Lesiów, T. (2011). Evaluation of the effectiveness of programs to ensure stable quality and food safety - preliminary study. In M. Filipiak, D. Gwiazdowska, \& H. Śmigielska (Eds.), Current trends in commodity science. „Quality and Safety of Food" (pp. 181-193). Poznań: Wydawnictwo UE w Poznaniu.

Orzechowska-Przybyła, K., Niewelt, A., \& Lesiów, T. (2014). Audit as a tool for development of innovative economy. In F. Adamczuk, \& A. Salus (Eds.), ISO 9001:2015 - new standard, new challenges (pp. 125-132). Jelenia Góra: Wydawnictwo "AD REM", 8th International Conference of Young Scientists of the Euroregion's Neisse, High Schools in Jelenia Góra.

Pia, P. (2010). Safety of a logistics chain: A case-study. Logistics Research, 2(3-4), 159-163.

The British Retail Consortium. (2018). Food safety and quality management system for food manufactures. Issue 8, The British Retail Consortium, UK.

Waligóra, L., \& Lesiów, T. (2009). Aspekty technologiczne a funkcjonowanie systemu HACCP w wybranym przedsiębiorstwie przemysłu mięsnego. Prace Naukowe Uniwersytetu Ekonomicznego we Wrocławiu. Nauki Inżynierskie i Technologie, 1(57), 1-123.

\section{Internet sources}

Food defense. (n.d.). In Wikipedia. Retrieved May 14, 2021 from https://en.wikipedia.org/wiki/Food_ defense

IFT. (n.d.). Retrieved September 1, 2016 from http://www.ift.org/knowledge-center/contract-reports/ food-defence-resource-list.aspx

QAP. (n.d.). Retrieved May 14, 2021 from https://haccp-polska.pl/food-defense 